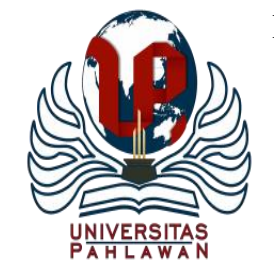

Edukatif : Jurnal Ilmu Pendidikan Volume 1 Nomor 3 Tahun 2019 Halaman 177-184

EDUKATIF: JURNAL ILMU PENDIDIKAN

Research \& Learning in Education

https://edukatif.org/index.php/edukatif/index

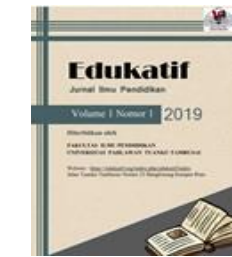

\section{MANFAAT SENI MUSIK DALAM PERKEMBANGAN BELAJAR SISWA SEKOLAH DASAR}

\section{Dwi Wulan Suci ${ }^{1}$}

Sekolah Dasar Negeri 07 Pasaman Kabupaten Pasaman Barat, Sumatera Barat, Indonesia dwiwulansucim@gmail.com ${ }^{1}$

\begin{abstract}
Abstrak
Musik adalah karya seni yang menggambarkan ide, pikiran dan perasaan manusia melalui keindahan dan irama dan nada-nada yang teratur. Musik memiliki manfaat dalam perkembangan belajar siswa sekolah dasar. Diantaranya terhadap hasil belajar, emosional, intelejensi, daya ingat dan konsentrasi. Peserta didik yang dari kecil terbiasa mendengarkan musik terbukti kecerdasan emosionalnya akan lebih berkembang. Anak dan musik memiliki keterkaitan yang kuat, musik bermanfaat untuk meningkatkan kecerdasan anak dan perkembangan belajar anak. Anak usia tiga sampai 6 tahun mengembangkan kecerdasan emosinya dengan mendengarkan lagu, karena masa itu merupakan masa yang paling baik pada perkembangan pendengarannya. Oleh sebab itu penulis tertarik mengkaji manfaat musik pada perkembangan belajar peserta didik sekolah dasar.
\end{abstract}

Kata Kunci : manfaat, seni, musik

\begin{abstract}
Music is a work of art that illustrates ideas, human thoughts and feelings through beauty and rhythm and regular tones. Music has benefits in the development of elementary school student learning. Among them are learning outcomes, emotional, intelligence, memory and concentration. Students who from childhood used to listen to music proved to be more developed emotional intelligence. Children and music have strong links, music is useful for increasing children's intelligence and children's learning development. Children aged three to 6 years develop emotional intelligence by listening to songs, because this is the best time for the development of hearing. Therefore the author is interested in studying the benefits of music in the development of elementary school student learning.
\end{abstract}

Keywords: benefits, art, music

@Edukatif: Jurnal Ilmu Pendidikan FIP UPTT 2019

$\triangle$ Corresponding author :

Address :-

Email :-

ISSN 2656-8063 (Media Cetak)

Phone :- 


\section{PENDAHULUAN}

Musik merupakan kebutuhan secara menyeluruh bagi manusia. Bagian dari seni yang dapat memberikan warna pada kehidupan dan pembentukan watak manusia. Musik menjadi salah satu kegemaran mulai dari generasi anak -anak, dewasa bahkan tua. Musik adalah salah satu seni yang nyata dan merupakan wujud bunyi pada fisika yang memiliki banyak manfaat atau keuntungan yang dapat merangsang pembentukan watak dan budi pekerti manusia. Bagi manusia yang suka menghayati musik, hidupnya akan terasa sepi, kurang bergairah dan tak bermakna tanpa musik. Musik dapat membangkitkan gairah dan semangat tersendiri bagi peningmat dan pelaku musik. Mencipta, mendengarkan dan menikmati musik merupakan kesenangan tersendiri bagi para musisi dan penikmat musik. Musik dapat membentuk pribadi manusia, membentuk kebudayaan pada masyarakat (Putri, 2012).

Pembelajaran Seni Musik dalam kurikulum 2013, adalah bagian mata pelajaran dalam rumpun Seni Budaya Dan Prakarya (SBDP) Guru yang bertanggung-jawab mengajarkannya adalah guru kelas. Jorgensen (dalam Fitriani, 2015) mengatakan, pendidikan musik dan musik itu sendiri memiliki manfaat yang signifikan terhadap perkembangan manusia dari mulai dari embrio di dalam rahim sampai akhir hayatnya.
Dalam mencapai tujuan pendidikan nasional yaitu membentuk manusia Indonesia seutuhnya, salah satunya dengan memberikan pendidikan seni yang berkulaitas oleh guru dan memberikan sumbangan yang sangat besar terhadap pembentukan karakter, sifat manusia (Ktsp \& Utomo, 2010).

Menurut Elliot (Fitriani, 2015) pendidikan musik antara lain: education in musik yang berisi nilai-nilai yang tesirat dan terkandung dalam pembelajaran musik. Education about musik yang berisi teori-teori dalam pembelajaran musik education for musik yang berisi tujuan mempelajari musik itu sendiri serta education by means of musik yang berisi gabungan hubungan dari ketiga pendidikan seni yang telah disebutkan sebelumnya. semestinya pendidikan seni menjadi panduan bagi guru dan harus dipahami dengan sebaik-baiknya . Di sekolah dasar pendidikan musik hendaknya disesuaikan dengan tingkat perkembangan pengetahuan siswa Sekolah Dasar (SD) dengan mempedomani keempat hakikat pendidikan seni tersebut.

Giyartini (Fitriani, 2015) menjelaskan bahwa perkembangan siswa sekolah dasar adalah masa yang paling kritis dalam hal imajinasi. Padahal pada dasarnya setiap anak memiliki kekayaan imajinasi namun apabila tidak tepat dalam penyaluran imajinasi tersebut justru dapat memberikan dampak yang tidak baik terhadap diri dan lingkungannya. Selain itu siswa sekolah dasar 
juga sulit focus, sifat khas mereka adalah mudah berubah konsentrasinya, mereka umumnya tertarik mencoba hal-hal baru yang lebih menarik minat mereka dan haus akan pengetahuan-pengetahuan baru. Oleh sebab itu hendaknya sekolah menyediakan fasilitas, sarana dan prasarana, dan media bagi penyaluran imajinasi dan kreativitas siswa kea rah yang baik melalui pembelajaran seni yang berkualitas.

Istilah musik dapat didefinisikan sebagai suatu kebutuhan pokok bagi setiap manusia, karena musik dapat menjadikan orang merasa senang, gembira dan nyaman. Musik bisa mengatasi kebosanan dan menangkal kebisingan eksternal yang mengganggu. Musik juga dapat membantu kita merasa bertenaga, percaya diri, mengurangi kesedihan, menghapus kemarahan, melepaskan stress serta mengurangi rasa takut dan cemas (Fauziah, 2011)

Plato mengemukakan pandangannya tentang musik "Musik is a moral law. It gives soul to the universe, wings to the mind, flight to the imagination, and charm and gaiety to life and to everything”. Musik sebagai bentuk dari hukum moral yang memberikan jiwa pada alam dan lingkungan. Musik merupakan imajinasi dan gambaran luapan dari emosi dan perasaan manusia. Meskipun musik tidak terlihat, namun dapat memberikan ketenangan dan gairah dan keceriaan hidup bagi penikmatnya. $(1392,1$ j).
Dengan memiliki hubungan begitu erat ke lubuk hati kita, masuk akal memang bahwa musik menggugah hati kita, membantu kita menciptakan hubungan emosional. Manusia dalam menunjukkan ekspresi marah, senang, bahagia, sedih, marah dan sebagainya dengan cara yang berbeda. Contohnya ketika siswa diberikan kesempatan bermain di dalam kelas, mereka menunjukkan ekspresi yang sangat senang sekali dan ketika marah, ekspresi yang ditunjukkan pun berbeda seperti, membanting benda yang ada didekatnya atau berkelahi dengan teman dan terkadang emosi siswa sulit dikendalikan. Menurut Howes dan Heral (Fauziah, 2011) menjelaskan kecerdasan emosional adalah bagian yang membuat seseorang menjadi pintar dalam menggunakan emosinya, membentuk karakter, sifat, pola piker dan sudut pandang siswa sekolah dasar.

Menuut Gardner terdapat hubungan keterkaitan antara musik dengan intelejensi seseorang. Kecerdasan musikal mempengaruhi kecerdasan-kecerdasan yang lain. Lagu dan gerak melibatkan keterampilan motorik, kecerdasan intelektual dan emosi (Felix, 2012). Dari pernyataan tersebut jelas bahwa musik mempunyai peranan yang sangat penting dalam perkembangan belajar peserta didik karena musik merupakan luapan perasaan manusia dengan bahasa yang mudah dimengerti. Sebuah studi di Jerman yang melibatkan 194 anak laki-laki kelas 3 Sekolah 
Dasar (SD) menunjukkan, kecerdasan non-verbal dan keterampilan membaca anak-anak yang belajar memainkan alat musik lebih tinggi dibandingkan dengan yang tidak. Studi lain di Amerika Serikat, yang melibatkan anak SD usia 7-12 tahun menunjukkan, anak-anak yang mendapat pendidikan musik lebih lancar membaca dan berbahasa daripada yang tidak sama sekali.

Musik dapat diartikan sebagai suatu kebutuhan bagi manusia. Dengan musik sesorang dapat menjadi senang, gembira rilek dan nyaman. Selain itu musik juga dapat mengusir kebosanan dan membantu manusia mengurangi kesedihan, menghapus kemarahan, mengurangi rasa cemas dalam diri. Tubuh manusia membutuhkan musik agar menjadi lebih rileks dan nyaman. Karena dengan keadaan yang tidak nyaman, tegang maka kerja otak juga akan menurun (Apriyani, 2015).

Motivasi belajar dapat ditingkatkan melalui musik, karena musik tidak hanya memberikan hiburan namun juga menjadi sarana sesorang mengungkapkan perasaannya dan memotivasi sesorang untuk melakukan sesuatu baik yang positif maupun sesuatu hal yang negative. (Pendidikan, Indonesia, Roffiq, Qiram, \& Rubiono, 2017).

\section{METODE PENELITIAN}

Metode yang digunakan dalam penulisan artikel ini adalah Literature review atau tinjauan pustaka. Yang digunakan untuk memahami suatu konsep yaitu manfaat musik bagi perkembangan belajar siswa sekolah dasar. Dengan membaca dan mengevaluasi penelitian-penelitian sebelumnya mengenai manfaat musik dalam perkembangan belajar siswa sekolah dasar. Membahas dengan menggunakan teori yang relevan untuk menjelaskan suatu konsep atau gambaran yang dibangun dengan menggeneralisasi suatu pengertian. Sebagai generalisasi, teori memberikan rangkuman terhadap generalisasi empirik dan antar hubungan dari berbagai proposisi yang didasarkan pada asumsi-asumsi tertentu baik yang akan diuji maupun yang telah diterima.

\section{HASIL DAN PEMBAHASAN PENELITIAN}

Merujuk hasil penelitian yang dilakukan mengenai pengaruh musik terhadap kecerdasan emosi siswa sekolah dasar menggambarkan bahwa penerapan musik dalam pembelajaran memiliki pengaruh yang signifikan terhadap kecerdasan emosi anak. Musik memberikan manfaat positif yaitu menghasilkan peningkatan terhadap suasana hati yang positif dan sebaliknya.dengan mendengarkan musik siswa menjadi bergairah dalam belajar dan menimbulkan rasa senang dalam dirinya. Sehingga materi pembelajaran mudah dapat sampai ke peserta didik. Emosi siswa juga lebih tenang ketika mereka mendengarkan musik. Mendengarkan musik-musik yang positif akan menjadikan dan membawa suasana hati sesorang menjadi tenang dan damai, sesorang yang 
melankolis memakai musik yang positif untuk menimbulkan perasaan ceria dan riang dalam dirinya.sedangkan untuk tipe yang tempramen lebih cocok mendengarkan lagu dan musik yang lembut untuk membuat kedamaian hati. Musik memang tidak dengan segera mengubah kepribadian sesorang, namun musik bias dengan cepat mengubah suasana hati (Desain \& Charles, 2002).

Salah seorang peneliti dari timutr tengah mengunggkapkan musik yang menggunakan tempo lambat dapat memberikan ketenangan, kedamaian, pengembangan emosional, spiritual, gangguan psikosomatik. Musik dengan tempo lambat dapat dijumpai dalam semua genre musik salah satunya musik instrument yang menunjukkan adanya hubungan antara emosi sesorang dengan musik yang didengarnya (Ktsp \& Utomo, 2010).

Efek musik juga dikemukakan dalam sebuah penelitian yang dilakukan tentang efek musik terhadap daya ingat siswa sekolah dasar menemukan hasil, dengan mendengarkan musik terbukti dapat meningkatkan daya ingat. Musik dengan komponen berirama kuat berakibat pada adaptasi motorik, sensori integrasi, proses kognitif dan gerakan fisiologis umum. Seseorang yang bermain musik cenderung lebih konsentrasi dan perhatian, gerakan tubuhnya umumnya teroganisir dengan baik sehingga respon fisiologisnya lebih mudah diatur. Hasil penelitian efek musik dan suara Morton, menjelaskan bahwa pengaruh mendengarkan musik adalah meningkatkan memori jangka pendek, mengurangi kebingungan dan meningkatkan proses informasi Hidayat (2011) mengemukakan pengaruh musik terhadap peningkatan kemampuan akademik sudah lama diyakini, selain dapat berpengaruh positif terhadap kualitas kehidupan anak-anak, juga dapat merangsang keberhasilan akademik jangka panjang, karena musik dan lirik membuat individu lebih mudah mengingat. Riset mengenai penggunaan musik untuk membantu proses belajar telah berlangsung cukup lama. Musik adalah bahasa yang mengandung unsur-unsur universal, yaitu penggunaan dan pemilihan bahasa yang puitis yang dapat dipahami dan dinikmati orang banyak tidak hanya golongan tertentu atau tidak hanya berdasarkan jenis kelamin, ras, agama, dan kebangsaan. Musik muncul di semua tingkat, kelas sosial, prestasi pendidikan (Budianto, 2007).

Penelitian lain yang mengungkapkan manfaat musik antara lain dapat menurunkan hormon-hormon stress dan bahkan menghilangkan. Musik dapat mengaktifkan hormon endofrin alami dan dapat meningkatkan perasaan tenang dan rilek. Metode yang digunakan dalam penelitian yaitu metode terapi musik. Penelitian tentang manfaat musik telah banyak dilakukan oleh para ahli. Musik-musik klasik diyakini banyak memberikan efek yang baik bagi manusia, dapat menciptakan ketenangan emosi, menghilangkan stress dan dapat membuat rileks. Pada penelitian ini, musik yang 
digunakan yaitu dengan mendengarkan murottal Alquran berupa rekaman suara alquran yang dilakukan oleh seorang qori (pembaca alquran lantunan alquran yang merdu terbukti mampu memberikan ketenangan dan perkembangan kognitif yang dapat mempertajam daya ingat dan menciptakan pemikiran yang cemerlang. Murottal alquran mengandung unsur suara dan irama yang menjadi alat penyembuhan stress yang menakjubkan. Para ilmuwan dari University of Missouri setuju bahwa mendengarkan musik dapat memperbaiki suasana hati. Penelitian yang dipublikasikan dalam The Journal of Positive Psychology ini mengungkapkan bahwa perbaikan mood dan penurunan tingkat stres tampak terlihat setelah 2 minggu rutin mendengarkan musik. (Apriyani, 2015).

Menurut para filusuf musik, Musik melibatkan kepada aspek psikologi, yang melibatkan pemikiran manusia, pendapat, abstraktif dan emosi. Sehingga kehidupan seseorang tidak akan terlepas dari pengaruh musik. Dalam sebuah penelitian pembelajaran yang menggunakan pengantar musik pada pelaksanaannya mendatangkan manfaat terhadap suasana kelas dan lingkungan belajarnya. Peembelajaran dengan menggunakan pengantar musik yang bernuansa menenangkan memiliki pengaruh yang signifikan terhadap hasil belajar siswa. Suasana lingkungan belajar dan kondisi kelas sangat berpengaruh terhadap hasil belajar siswa. Kondisi kelas yang nyaman dan kondusif dapat diciptakan dengan cara memberikan musik (Pgsd, Pendidikan, \& Negeriisurabaya, 2007).

Penelitian lain tentang manfaat seni dalam meningkatkan konsentrasi belajar dengan mendengarkan musik. Musik berpengaruh terhadap konsentrasi belajar siswa dengan memperdengarkan musik Heavy Metal dan Degung Sunda, serta tidak diperdengarkan musik apapun. Peneliti menemukan pengaruh yang cukup kuat dari musik latar yang diperdengarkan terhadap konsentrasi belajar siswa. (Ellfira, 2015).

Sebuah studi yang dilakukan yang dimuat dalam website live science menyatakan bahwa orang yang bermain musik dapat merespon bahasa dan suara dengan lebih baik. Mereka cenderung akanlambat dalam proses penuaan otak. Disamping itu, bermain alat musik dapat meningkatkan kemampuan seseorang untuk dapat mendengar dalam suasana rebut. Suara merupakan factor lingkungan. Dalam pembelajaran matematika, siswa dapat menerima pembelajaran dengan baik apabila tidak ada suara bising atau ribut dan mengganggu. Suasana yang tidak nyaman menimbulkan kecemasan kepada siswa. Namun ada pula suara yang dapat meningkatkan semangat belajar siswa seperti suara musik, lagu yang dapat menenangkan. Untuk menghilangkan kecemasan dalam pembelajaran matematika, banyak metode yang dapat digunakan. Salah satunya dengan menggunakan metode penggunaan 
musik yang terbukti memberikan rasa tenang, nyaman mengendalikan emosi pengembangan aspek spiritual, moral dan dapat memberikan perasaan rileks (Susanti, Devi W. dan Rohmah, 2011).

Pembelajaran seni musik disekolah dasar, materi ddan konteksnya harus disesuaikan dengan kabutuhan dan perkambangan usia, kematangan emosinya dan memberikan keseimbangan otak kanan dengan otak kiri, keseimbangan antara kecerdasann emosional, intelektual dan spiritual. Musik yang dipelajari dapat terkait dengan kebesaran Allah sebagai pencipta manusia dan alam, memperkenalkan bunyi-bunyian yang berasal dari alam atau bunyi-bunyian buatan, keindahan alam, peristiwa alam, kasih sayang, nasehat, bela negara, cinta tanah air, dan memberikan pengalaman untuk mengenal hubungan sosial dan budaya. Dengan arti kata semua materi atau konten yang diberikan diikuti dengan pemaknaan terhadap unsur-unsur yang terdapat pada musik itu sendiri. Misalnya dalam mempelajari dan menyanyikan berbagai macalam lagu daerah, peserta didik dapat berekspresi, mengapresiasi, berkreasi, membentuk harmoni, dan menikmati keindahan musik dan dilanjutkan dengan mengekplorasi makna atau isi lagu yang dinyanyikan. Sehingga lagu tersebut dapat memberikan pemahaman terhadap ciri khas budaya yang terdapat pada masing-masing daerah serta dapat menjadikan peserta didik memahami budaya masing-masing daerah tersebut. Sehingga dari proses mempelajari atau menyanyikan berbagai macam lagu daerah, dapat menumbuhkan kesadaran dan kepedulian diri akan keanekaragaman budaya dan kehidupan yang terdapat di nusantara ini. Sehingga pembelajaran yang dilakukan secara menyeluruh dapat memberikan input bagi peserta didik dengan memberikan haknya sebagai manusia yang hidup dalam beberagaman. Pemerolehan.

\section{KESIMPULAN}

Musik yang digunakan sebagai media pembelajaran, dapat membantu pembelajaran menjadi lebih menyenangkan. Musik dapat menyeimbangkan antara kecerdasan emosional, intelejensi dan spiritual. Musik dapat membantu menyeimbangkan kerja otak kiri dengan otak kanan. Musik dapat memberikan ketenangan dan kenyamanan suasana dan lingkungan belajar siswa. Musik juga dapat digunakan dalam relaksasi untuk memperoleh konsentrasi dalam menerima pembelajaran. Dengan musik dapat membantu merangsang ingatan, berbahasa, dan analisis agar menjadi manusia yang memiliki pemikiran logis, kritis, cerdas dan kreatif.analisis,

\section{DAFTAR PUSTAKA}

Apriyani, Y. (2015). Pengaruh Terapi Murottal terhadap Konsentrasi Belajar Siswa Kelas V SD Muhammadiyah 2 :Pontianak. Keperawatan.

Budianto, I. M. (2007). Memahami Seni dan Estetika. Wacana, Journal of the Humanities of Indonesia, 9(1), 124. https://doi.org/10.17510/wjhi.v9i1.227 
Desain, P., \& Charles, A. (2002). Sekolah tinggi seni musik di jakarta.

Ellfira, S. (2015). Hubungan Karakter Musik Klasik Dan Pop-Jazz Dengan Kecerdasan Emosi ( $E Q$ ). 64.

Fauziah, Y. N. (2011). Analisis Kemampuan Guru Dalam Mengembangkan Keterampilan Berpikir Kreatif Siswa Sekolah Dasar Kelas $V$ Pada Pembelajaran Ilmu Pengetahuan Alam. Edisi Khusus, (2), 98-106.

Felix, J. (2012). Pengertian Seni sebagai Pengantar Kuliah Sejarah Seni Rupa. Humaniora, 3(2), 614. https://doi.org/10.21512/humaniora.v3i2.340

Fitriani, Y. (2015). Model Pembelajaran Seni Musik melalui Lesson Study: Studi Kasus di SDN Jawilan, Serang. Resital: Jurnal Seni Pertunjukan, 15(2), 126-138. https://doi.org/10.24821/resital.v15i2.847

Ktsp, S. P., \& Utomo, U. (2010). Model Pengembangan Materi Pembelajaran Seni Musik Di Sd/Mi Berdasarkan Kurikulum Tingkat Satuan Pendidikan (Ktsp). Jurnal Penelitian PendidikanA \& A (Semarang), 27(2). https://doi.org/10.15294/jpp.v27i2.176

Pendidikan, J., Indonesia, D., Roffiq, A., Qiram, I., \& Rubiono, G. (2017). $M m d l p p p$. (September), 35-40.

Pgsd, J., Pendidikan, F. I., \& Negeriisurabaya, U. (2007). Matematika Siswaikelas V Sekolah Dasar Kurniawan Wahyu Pratama Yoyok Yermiandhoko Abstrak. 2897-2908.

Putri, N. (2012). Efektifitas Penggunaan Media Video Untuk Pada Pembelajaran Ips Bagi Anak Tunagrahita Ringan. Jurnal Ilmiah Pendidikan Khusus, 1, 318-328.

Susanti, Devi W. dan Rohmah, F. A. (2011). Efektivitas musik klasik dalam menurunkan kecemasan matematika. Humanitas, 8, no 2(Agustus), 130-142. Retrieved from http://www.academia.edu/download/4052409 6/peran-religious-coping-sebagai-moderatordari-job-insecurity-terhadap-stres-kerja-padastaf-akademik.pdf

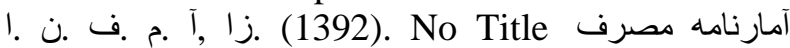
فر آورده هاى نفتى انرزى زار أ.

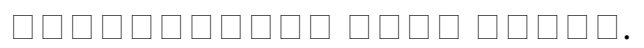

